\title{
Suitability of phytoliths as a quantitative process tracer for soil erosion studies
}

\author{
Sabine Kraushaar ${ }^{1} \odot$ | Matthias Konzett ${ }^{1} \odot$ | Janika Kiep ${ }^{2} \odot$ | \\ Christian Siebert $^{3} \odot$ । Julia Meister ${ }^{4}$ ()
}

${ }^{1}$ Department of Geography and Regional Research, ENGAGE - Geomorphological Systems and Risk Research, The University of Vienna, Universitätsstrasse 7, Vienna, 1010, Austria

${ }^{2}$ Institute of Geographical Sciences, Freie Universität Berlin, Berlin, Germany

${ }^{3}$ Helmholtz Centre for Environmental Research - UFZ, Halle, Germany

${ }^{4}$ The University of Würzburg, Institute of Geography and Geology, Würzburg, Germany

\section{Correspondence}

Sabine Kraushaar, The University of Vienna, Department of Geography and Regional Research, ENGAGE - Geomorphological Systems and Risk Research, Universitätsstrasse 7, 1010 Vienna, Austria. Email: sabine.kraushaar@univie.ac.at

\section{Funding information}

Student stipend from the Department of Earth Sciences of the Freie Universität Berlin; Woman in Science fund by the Faculty of Earth Sciences, Geography and Astronomy at the University of Vienna

\begin{abstract}
Phytoliths are plant microfossils commonly used as qualitative archive markers in archaeological and paleoecological studies. Their potential uniqueness to the vegetation cover, robustness to weathering, and lack of chemical alteration along the transport paths make them potentially suitable tracers for quantitative erosion studies. In this pilot study, we explore the potential of phytoliths in a sediment fingerprinting study in the Ceguera catchment $\left(28 \mathrm{~km}^{2}\right)$ in NE Spain. The phytolith concentrations and morphologies of four land cover classes (agricultural land, badland, forest, and shrubland) were analysed, and their contributions to four natural sediment mixture samples along the river course were modelled. Phytolith concentrations allowed us to discriminate sources sufficiently, albeit with limited sample size. The performance of the phytoliths as tracer was tested by reproducing the sources of artificial sediment mixture samples with satisfactory recall ratio. Results identified badlands to be the main contributor, with $84-96 \%$ of the sediment load to the sinks, followed by shrublands (median 5\%) and agricultural lands (median 2\%). These major findings can be reproduced by other conventional erosion studies from this area, indicating that phytoliths are suited to quantifying erosion patterns in mesoscale catchments.
\end{abstract}

KEYWORDS

erosion, FingerPro model, Isábena River, phytoliths, sediment fingerprinting

\section{1 | INTRODUCTION}

Silica phytoliths are microscopic bodies composed of amorphous silica that form within cells or in the extracellular spaces of plant tissue in many plant families, maintaining the shape of the original cell structure (Pearsall, 2000; Piperno, 1988). After the plant dies and the organic matter decays, phytoliths are released and usually incorporated into the soil or sediment system (Madella \& Lancelotti, 2012). Once deposited, phytoliths are quite resilient (Pearsall \& Trimble, 1984; Piperno, 2006), although phytolith assemblages can be affected by different forms of post-depositional processes (i.e. during pedogenesis and diagenesis) (Cabanes \& Shahack-Gross, 2015; Madella \& Lancelotti, 2012). Usually, the rate of phytolith dissolution increases significantly under alkaline conditions (Loucaides et al., 2008).
Phytolith production is widespread in the plant kingdom, including many monocotyledon, angiosperm, gymnosperm, and eudicot families (Piperno, 2006); therefore, it is not surprising that phytoliths occur in various sizes ( 1-250 $\mu \mathrm{m}$ ) and shapes (Strömberg, 2004). In terms of morphology, specific morphotypes can be assigned to certain parts of plants (e.g., leaf vs. inflorescence grass phytoliths) and even serve as identifiers of plant families, genera, or species (Mulholland \& Rapp, 1992a; Piperno, 2006). Hence, silica phytoliths are important plant microfossils that have been successfully used in numerous paleoecological and archaeological studies as qualitative proxies for past vegetation, climate variability, land use, and crop processing (e.g., Albert et al., 1999; Barboni et al., 1999; Dietrich et al., 2019; Neumann et al., 2009; Strömberg, 2004; Weisskopf et al., 2015).

The aim of this study was to assess if phytoliths can also serve as quantitative tracers in recent erosion studies using sediment

This is an open access article under the terms of the Creative Commons Attribution-NonCommercial License, which permits use, distribution and reproduction in any medium, provided the original work is properly cited and is not used for commercial purposes.

(c) 2021 The Authors. Earth Surface Processes and Landforms published by John Wiley \& Sons Ltd. 
fingerprinting. As Haddadchi et al. (2013) point out, a variety of physical, chemical, and biological tracers had been implemented in the past in fingerprinting studies, including sediment colour (Boudreault et al., 2018), major and trace elemental compositions (Kraushaar et al., 2015), and pollen contents (Brown, 1985).

In order to be recognized as a suitable tracer, a property needs to be measurable and conservative, meaning unique for the different kinds of sources they need to discriminate and not to be altered with time or along a transport path or by post-depositional processes (Collins et al., 2017; Haddadchi et al., 2013; Koiter et al., 2013; Kraushaar et al., 2015; Owens et al., 2016; Smith \& Blake, 2014). In this regard, specific properties make phytoliths potentially very conservative and, therefore, a suitable quantitative process tracer for erosion studies. These properties include potentially unique compositions and concentrations of phytolith assemblages for different land cover classes, as well as their physical and chemical constancy along a transport path due to their silica composition.

However, due to a variety of physical, chemical, biological, and anthropogenic factors that underlie the production, dispersion, deposition, and conservation of phytoliths, several tracer-related challenges potentially exist that need to be thoroughly addressed. These include: (i) change of vegetation zones or land use and the potential inheritance of older phytolith assemblages; (ii) change of phytolith assemblages by sediment erosion and/or deposition (e.g., fluvial, aeolian); (iii) weathering, physical corrosion, and dissolution on site, during transport and post-deposition affecting the preservation of phytolith assemblages; and (iv) particle size selection processes during sediment transport rendering the phytolith concentrations.

The use of phytoliths in sediment fingerprinting has not yet been studied, nor their potential as natural and therefore non-inversive tracers explored. Hence, this study aims to investigate these potentials and challenges of phytoliths serving as a quantitative process tracer for soil erosion in a medium-size sub-catchment of the Isábena River in the Spanish Pyrenees by addressing the following key questions: (1) Are phytoliths suitable for use as a quantitative tracer in terms of uniqueness, constancy in time, and constancy along a transport path? (2) How well do phytolith tracers perform with regard to observed erosion processes in the different land cover classes, as well as when deciphering artificial sediment mixture samples?

\section{2 | STUDY AREA}

The Ceguera is a sub-catchment of the Isábena River in the NE of Spain and covers $28 \mathrm{~km}^{2}$ (Figure 1). Elevations range from 600 to $1355 \mathrm{~m}$ above sea level in the headwaters of the catchment, and the geological base is characterized by a homogeneous carbonate-free sandstone with small areas of conglomerates (Palazón et al., 2015). The dominant morphology shows $\mathrm{V}$-shaped valleys and steep slopes guaranteeing good lateral connectivity of the sediment to the river. The riverbed is mainly bedrock with a few gravels, indicating good longitudinal connectivity. Based on the Corine Land Cover (CLC) map from 2018 , most of the area is covered by shrubs (47.7\%), followed by forests (37.9\%), agricultural land (14.3\%), and badlands (0.1\%; CLC, 2018). However, this can only be a rough estimate of the spatial distribution of the different land cover classes, as field observations have shown that the existence of badlands, for example, is likely to be underestimated due to the resolution and accuracy of the data set.

Substantial land abandonment has occurred in the last 60 years in the region, resulting in the succession of what were formerly agricultural fields, resulting in high erosion rates (Arnaez et al., 2011; LópezVicente et al., 2011). Consequently, reservoirs in the surrounding of the study area suffer from sedimentation, reducing their storage capacity with serious effects for water and energy security (Palazón et al., 2015).

Thus, the catchment has been the focus of intense hydrological and erosion studies since the late 1990s (Bronstert et al., 2014; Brosinsky et al., 2014a, b; Fargas et al., 1997; Francke et al., 2014; López-Tarazón et al., 2009, 2010, 2011, 2012; Palazón \& Navas, 2016, 2017; Palazón et al., 2015, 2016; Valero-Garcés et al., 1999) and is, therefore, in this regard well understood, which makes it suitable to test new tracers (Brosinsky et al., 2014a).

\section{3 | METHODS}

\section{1 | Sample collection}

From each of the four land cover classes, we collected six composite sediment samples $(n=24)$. Each composite sample consisted of 20 subsamples from random topsoil locations within a 1-ha sample site. Near the sample location areas, there were evident signs of erosion, such as rills and gullies, signs of siltation, and loss of vegetation due to the erosion of the surface soil (Figure 1). An additional four natural sediment mixture samples (SM1-SM4) were collected from freshly deposited alluvial sediments deposited during the last floods, without current vegetation cover or signs of pedogenetic processes. Finally, and to test the performance of the tracers, five artificial sediment mixture samples (AM1-AM5) were prepared by mixing different percentages of the four sediment sources (Table 1).

\section{2 | Laboratory analysis}

Phytolith extraction followed the procedures outlined by Albert et al. (1999). Approximately $1 \mathrm{~g}$ of air-dried sediment $(<2 \mathrm{~mm})$ was treated with sufficient $3 \mathrm{~N} \mathrm{HCl}, 3 \mathrm{~N} \mathrm{HNO}_{3}$, and $\mathrm{H}_{2} \mathrm{O}_{2}$ to remove carbonates, phosphates, and organic material, respectively. The mineral components of the samples were separated according to their densities using $\sim 2.4 \mathrm{~g} / \mathrm{mL}$ sodium polytungstate solution $\left[\mathrm{Na}_{6}\left(\mathrm{H}_{2} \mathrm{~W}_{12} \mathrm{O}_{40}\right)\right.$ $\mathrm{H}_{2} \mathrm{O}$ ]. During microscopic preparation, about $1 \mathrm{mg}$ of sediment of the lightest fraction $(<2.3 \mathrm{~g} / \mathrm{mL}$ ) was placed onto a microscope slide and mounted with Entellan New (Merck). Counting was performed using a Leica DM 2000 microscope at 400× magnification; 200 phytoliths were identified and counted in each sample, wherever possible. Unidentifiable phytoliths were counted and recorded as weathered morphotypes. The phytolith concentrations were calculated as described by Albert et al. (1999) and normalized to the number of phytoliths per gram of sediment. Because phytoliths are enriched in topsoils after decomposition of the plants (Liu et al., 2019), the predicted phytolith concentrations of the topsoils investigated here are regarded as the actual phytolith concentrations derived from the aboveground vegetation. 


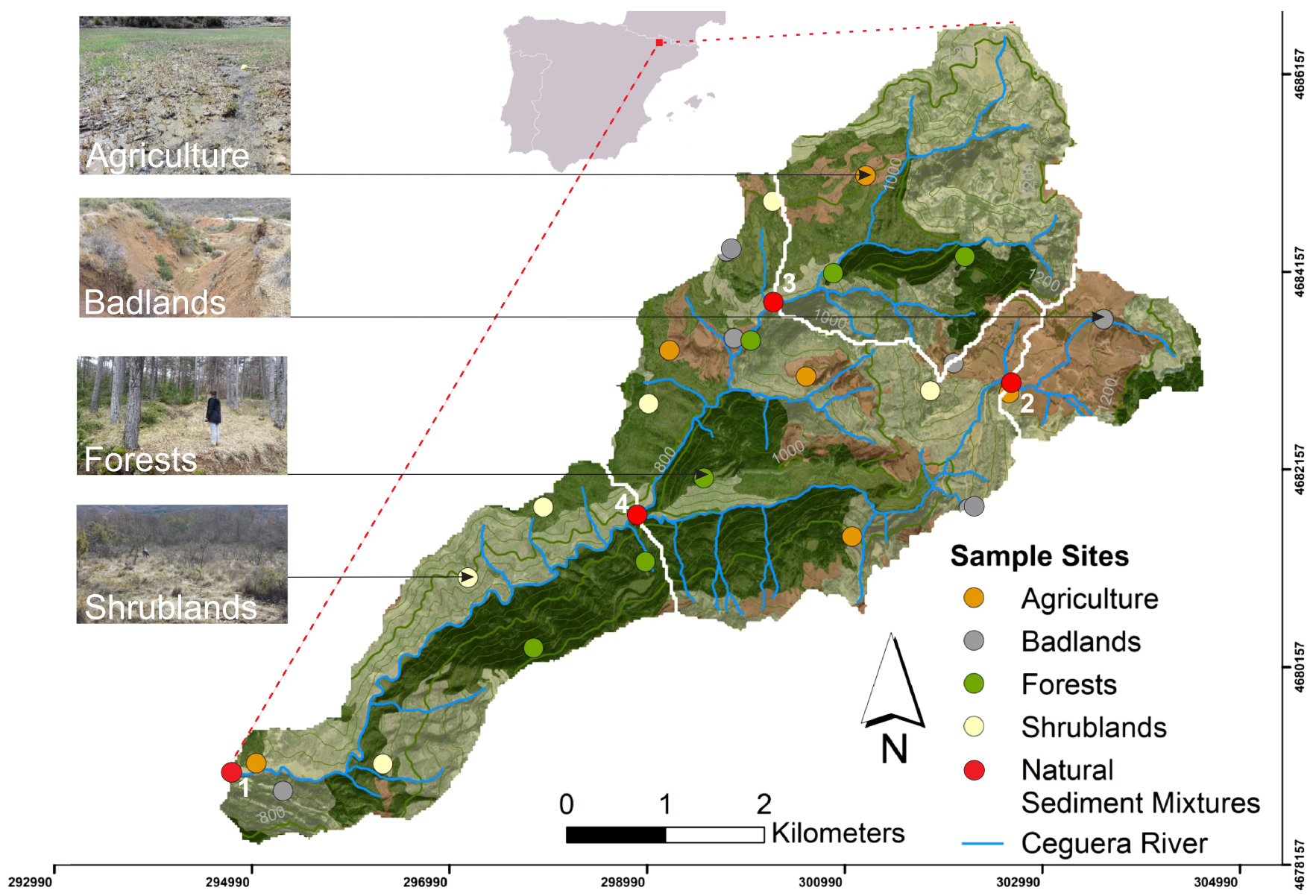

F I G U RE 1 Ceguera catchment with sample points. Numbers display the natural sediment mixture samples 1-4 (Orthophoto sources: Esri, DigitalGlobe, GeoEye, i-cubed, USDA FSA, USGS, AEX, Getmapping, Aerogrid, IGN, IGP, swisstopo, and GIS-Anwender-Community. Corine Land Cover map. Images: Kraushaar, 2018) [Color figure can be viewed at wileyonlinelibrary.com]

TA B LE 1 Artificial sediment mixture samples of different compositions and their modelled values (matching values are marked in bold)

\begin{tabular}{|c|c|c|c|c|c|c|c|}
\hline & $\begin{array}{l}\text { Agriculture } \\
\text { (\%) }\end{array}$ & $\begin{array}{l}\text { Badlands } \\
\text { (\%) }\end{array}$ & Forests (\%) & $\begin{array}{l}\text { Shrublands } \\
\text { (\%) }\end{array}$ & GOF (\%) & $\begin{array}{l}\text { No. estimated } \\
\text { sources }^{\mathrm{a}}\end{array}$ & $\begin{array}{l}\text { Highest minimum deviation from } \\
\text { the arithmetic mean (\%) }\end{array}$ \\
\hline AM1 & 30 & 10 & 40 & 20 & $70.4 \pm 7.6$ & $3 / 4$ & 16.21 \\
\hline AM1 modelled & $4.2 \pm 9.6$ & $27 \pm 17.7$ & $44.6 \pm 20.9$ & $24.3 \pm 19.1$ & & & \\
\hline AM2 & 30 & 40 & 10 & 20 & $89.9 \pm 4.6$ & $3 / 4$ & 6.61 \\
\hline AM2 modelled & $12.3 \pm 11.0$ & $49.6 \pm 13.5$ & $4.7 \pm 7.1$ & $33.3 \pm 15$ & & & \\
\hline AM3 & 40 & 10 & 15 & 35 & \multicolumn{3}{|c|}{$\begin{array}{l}\text { Sample excluded due to } 10 \text { times higher phytolith concentration } \\
\text { (measurement error assumed) }\end{array}$} \\
\hline AM4 & 15 & 15 & 30 & 40 & $95.6 \pm 2.6$ & $0 / 4$ & 44.84 \\
\hline AM4 modelled & $5.0 \pm 5.1$ & $69.2 \pm 9.4$ & $1.2 \pm 2.8$ & $24.6 \pm 8.9$ & & & \\
\hline AM5 & 25 & 25 & 25 & 25 & $70.6 \pm 3.9$ & $4 / 4$ & 0 \\
\hline AM5 modelled & $23.9 \pm 20.4$ & $13.6 \pm 14.3$ & $25.9 \pm 21.5$ & $36.7 \pm 16.9$ & & & \\
\hline
\end{tabular}

${ }^{a}$ Within the standard deviation of the modelled arithmetic mean.

The morphological identification of phytoliths was based on standard literature (Brown, 1984; Mulholland \& Rapp, 1992b; Piperno, 2006; Twiss et al., 1969), as well as on modern plant reference collections from the Mediterranean area (Albert, 2000; Albert \& Weiner, 2001; Portillo et al., 2014; Tsartsidou et al., 2007). The International Code for Phytolith Nomenclature was followed where possible (Madella et al., 2005).

\section{3 | Statistical analysis}

The commonly used fingerprinting approach, as described by Walling (2005), Collins et al. (2017), Haddadchi et al. (2013), Smith and Blake (2014), and Owens et al. (2016), was implemented using the updated R package 'FingerPro' by Lizaga et al. (2018, 2020a). The statistical pre-selection includes a range test and the Kruskal-Wallis 
$\mathrm{H}$-test $(\mathrm{KW}, p$-value $=0.05)$ to identify phytolith concentrations that allow the discrimination of at least two of the sediment sources. Using a discriminate function analysis (DFA) and a stepwise selection procedure of phytoliths based on the minimization of Wilks' lambda $(\Lambda=0.01)$, a minimum combination of tracers with the highest discriminatory power was chosen (Collins \& Walling, 2002; Gaspar et al., 2019). The subsequent mixing model within the $R$ package 'FingerPro' (CRAN; Lizaga et al., 2018, 2020a) was performed with 2000 iterations, to gain mean values and standard deviations per source.

Results were validated with four artificial sediment mixture samples, and compared to observed erosion processes and recent fingerprinting studies using chemical elements and radionuclides (Palazón \& Navas, 2017; Palazón et al., 2015, 2016) and magnetic properties (Brosinsky et al., 2014b) from the region.

\section{\begin{tabular}{l|l}
4 & RESULTS
\end{tabular}}

\section{1 | Phytolith concentrations}

As might be expected in soil samples, 6 out of 33 samples do not achieve the desired count of 200 phytoliths per sample, although they yielded at least 100 counts. The amount of phytoliths varies considerably within the samples from the four land cover classes, ranging from 1110 to 54690 phytoliths per gram of sediment (Figure 2, Table S1). The highest concentrations are observed in shrubland samples $(n=6)$ with a median of 32553 phytoliths per gram of sediment, while the lowest concentrations (median $=6632$ ) were observed in the badlands $(n=6)$.

Due to a nonreproducible error, nonrealistic phytolith concentrations of c. 300000 phytoliths per gram of sediment in artificial sediment mixture sample AM3, exceeding all other samples by a factor of 10 , led to its removal.

The phytolith amounts in the natural sediment mixture samples, as well as in the artificial sediment mixture samples, vary significantly, ranging from 3691 to 83803 phytoliths per gram of sediment in the natural sediment mixture samples $(n=4)$ and from 8917 to 32870 phytoliths per gram of sediment in the artificial sediment mixture samples $(n=4)$, reflecting the contributions from the different sediment sources.

\section{2 | Phytolith morphologies}

A total of 39 different morphotypes were identified in the samples studied (Table S2). Overall, the sediment sources and the natural sediment mixture samples are similar in their morphotype assemblages (Figure 3, Table S3). While about $0.6 \%(n=28)$ of the phytoliths were not morphologically identifiable, grass phytoliths, which occur at an average rate of $53.1 \%$ ( $S D=15.4, n=28$ ), are the most common group. According to their short cell morphologies, grasses belong mostly to the $\mathrm{C}_{3}$ Pooideae subfamily, with rondel short cells, commonly produced in leaves, stems, and inflorescences of Pooideae, occurring at an average concentration of $11.6 \%(n=28)$. Other common grass morphotypes are different types of a parallelepiped and elongate phytolith forms. However, due to the absence of multicellular phytoliths in the samples, it was not possible to identify the grass species. With an average value of $0.9 \%(n=28)$, the amounts of Dicotyledonous leave phytoliths are low, while Dicotyledonous wood/bark phytoliths account for $42.3 \%$ on average ( $S D=15.4, n=28$ ). Parallelepipedal blocky phytoliths, as one of the most common wood/bark morphotypes, for instance, were observed with an average concentration of $27.7 \%$ (SD $=17, n=28$ ). Globular echinates, commonly associated with palms (Arecaceae), and saddle short cells, produced within the $\mathrm{C}_{4}$ grass subfamily Chloridoideae, were combined into the group of 'Others', reaching an average concentration of $3.1 \%(n=28)$.

Generally, all sources show a higher concentration of grasses except for the badlands, where phytoliths of Dicotyledonous wood/ bark dominate.

\section{3 | Tracer selection and fingerprinting}

Following the statistical pre-selection procedure, five phytolith morphotypes were seen to be the optimum tracer combination for differentiating between the sources. These are elongate dendritic long cells, hair cells mesophyll, epidermal papillae cells, tall rondel short cells, and globulars echinate oblong (Figure 4). Elongate dendritic long cells, epidermal papillae cells, and tall rondel short cells are produced within grasses, while hair cells mesophyll are produced by Dicotyledonous leaves and globulars echinate oblong are often associated with palms (Arecaceae).

In Figure 5, the variability of tracer assemblages in each source is well observed. Badlands samples contain only one tracer (tall rondel short cells) with low concentrations, while forest samples host all five tracers. Shrublands and agricultural fields show-with three present tracers in different concentrations-a medium occurrence of tracer assemblages, and natural sediment mixture samples display only two phytolith tracers, hinting that forests are a less dominant source. When applying the selected tracers using linear discriminant function analysis (LDA), the corresponding LDA plot (Figure 6) shows that partial overlap between the variances of the sources exists, and that badlands are least well discriminated and are part of the agricultural scatter area as known from Brosinsky et al. (2014b).

Using the five phytolith morphotypes that compile the optimum tracer combination, four artificial sediment mixture samples were modelled. Results were compared to the actual amount of mixed source material. Figure 7 gives a graphical overview of the results (Table S4). Three of the final four artificial sediment mixture samples (AM1, AM2, AM5) show promising results. They classify three to four of the four sources within the range of the standard deviation (Table 1, Table S4), and display highest minimum deviations from the real values of only $0-16 \%$. Agricultural contributions are only correctly modelled in AM5. For AM4, none of the sources are correctly estimated, and modelling results show the highest deviations with c. $45 \%$ in the case of badlands (Table 1, Figure 7). This is unexpected, since procedures and contribution amounts were comparable to the other artificial sediment mixtures. The modelled samples exhibit goodness of fit (GOF) between 70 and $96 \%$. AM4, with no correctly estimated source contribution, showed the highest GOF value, with 95.6\%. Following Manjoro et al. (2017) and Gaspar et al. (2019), the quality assessments using this indicator seem to be inconsistent here. 

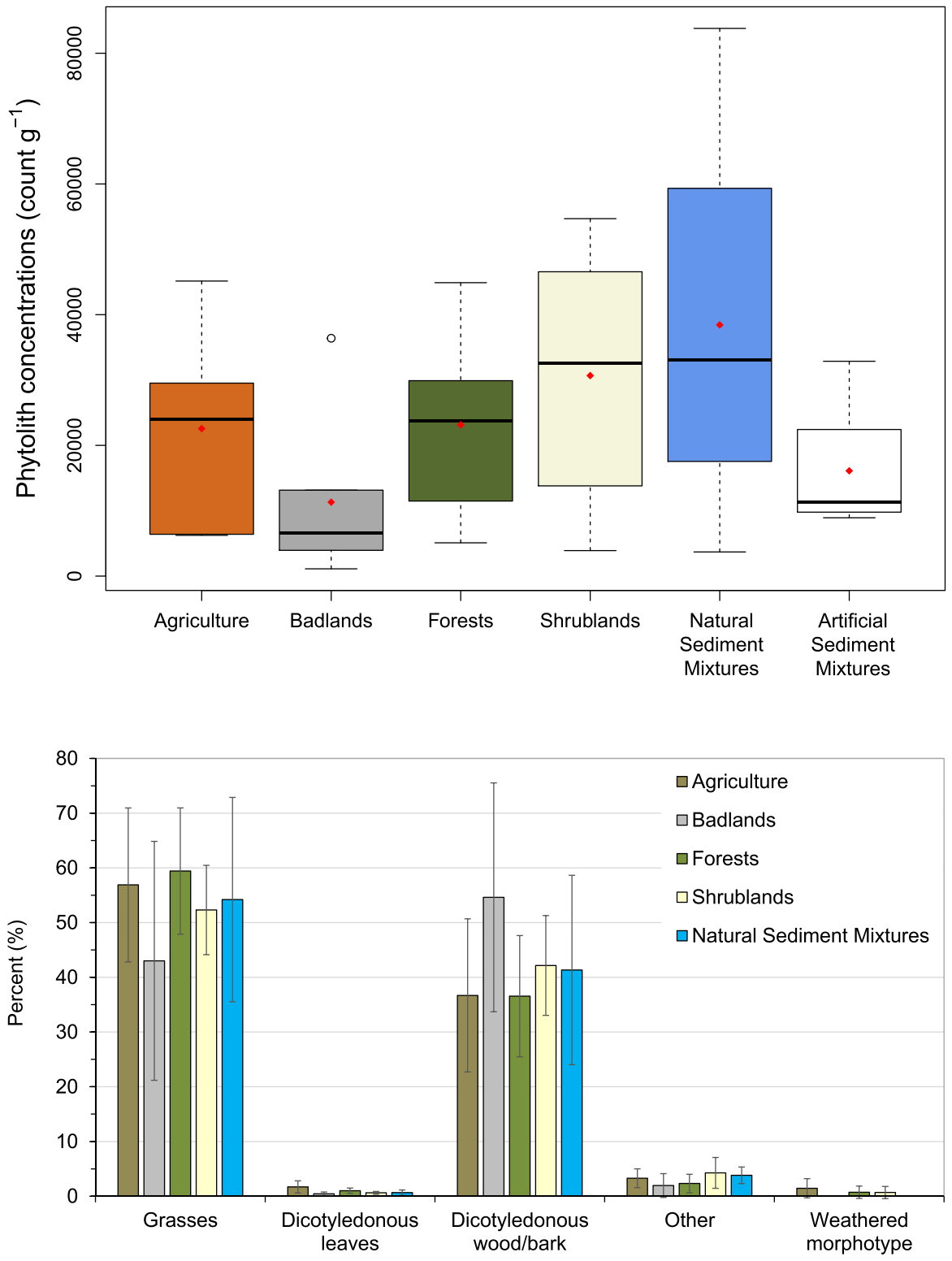

Elongate dendritic long cell

FIGURE 2 Phytolith concentrations per gram of sediment in the four sediment sources and natural sediment mixture samples. The bold line in the boxplots indicates the median; the red dots indicate the arithmetic mean [Color figure can be viewed at wileyonlinelibrary.com]

FIG URE 3 Relative abundances of phytoliths obtained from sediment sources and the natural sediment mixture samples [Color figure can be viewed at wileyonlinelibrary.com]

FIG URE 4 Drawing of the tracer phytoliths identified in the Ceguera catchment samples (modified after Madella et al., 2005) [Color figure can be viewed at wileyonlinelibrary.com]
Gaspar et al. (2019) even doubt the explanatory power of the GOF as a good enough index for model performance and claim that low GOF values (below 80\%; AM1 and AM5) rather hint at a random behaviour in the model or modelling error than a good unmixing of the natural sediment mixture samples.

The relative contribution to the four natural sediment mixture samples was calculated with the mixing model using again the five phytolith morphotypes that compile the optimum tracer combination (Figure 8, Table S4). In all natural sediment mixture samples except SM2, badlands seem to contribute by far the bulk of the sediments eroded (84-96\%) but represent the least well discriminated source which overlaps with agricultural areas. Shrublands (2-7\%) and agricultural areas $(1-7 \%)$ follow and in all samples, forests have the lowest relative contribution with $1-5 \%$ of the sediments (Figure 8 ). 


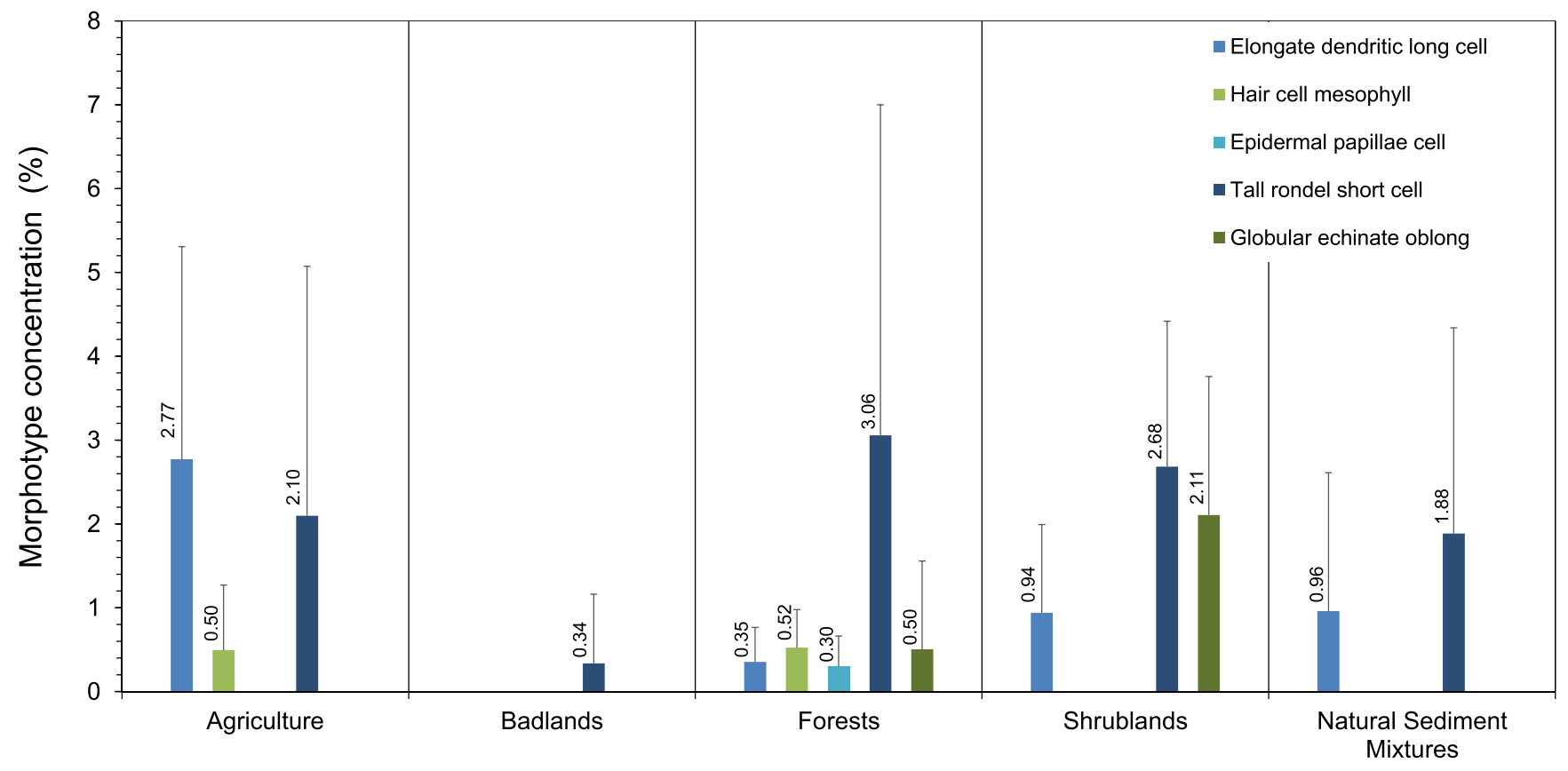

F I G U RE 5 Relative phytolith tracer assemblage in the four sediment sources and the natural sediment mixture samples. Morphotypes that do not appear were not present in the samples [Color figure can be viewed at wileyonlinelibrary.com]

F I G U RE 6 2D scatterplot of the linear discriminant analysis results [Color figure can be viewed at wileyonlinelibrary.com]

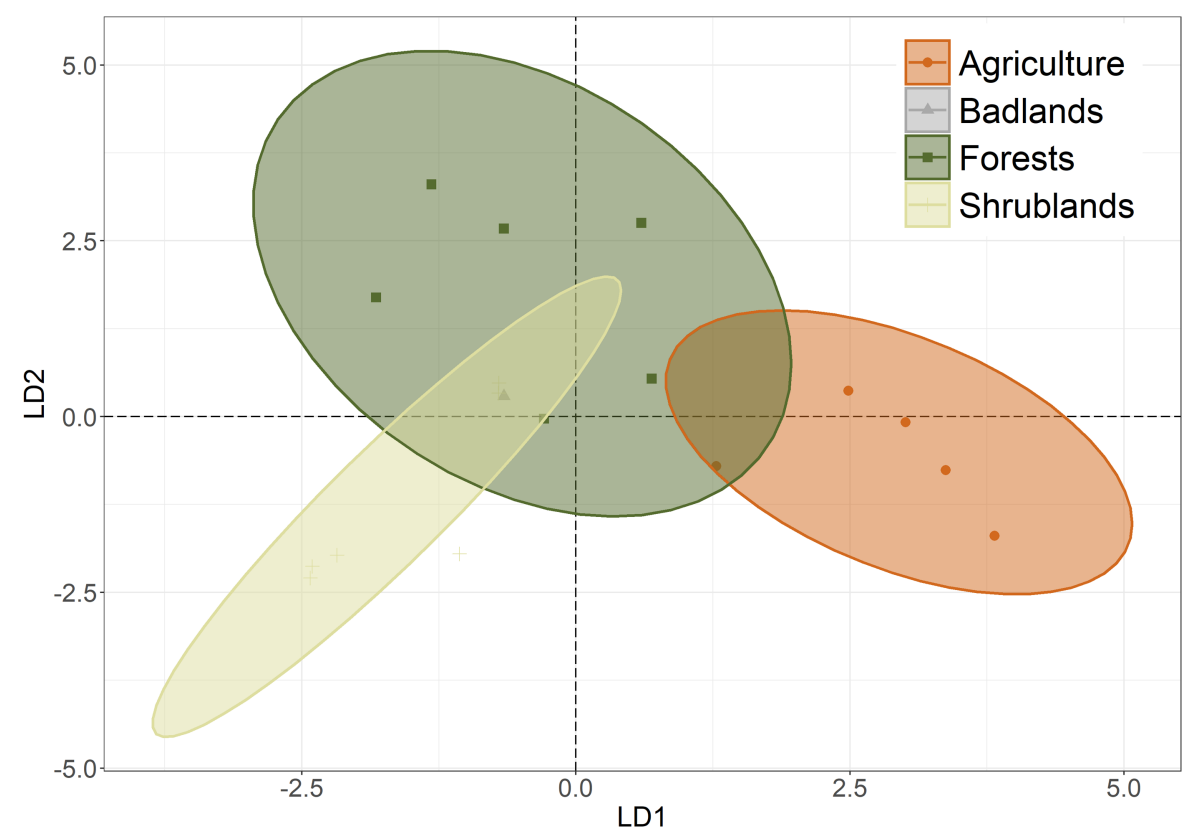

\section{5 | DISCUSSION}

\section{1 | Uniqueness}

Generally, phytolith production in the plant kingdom and morphological classification is complex, and uncertainties in the interpretation of phytolith data persist (Pearsall et al., 2004). While numerous plant families produce large quantities of phytoliths (e.g., Poaceae), other plant families or species produce no or only rarely phytoliths (e.g., Agavaceae), while production in other families varies substantially (e.g., Fabaceae; Piperno, 2006).

In terms of morphological classification, some phytoliths can be related to certain taxonomic groups, while the majority of phytolith types are produced in multiple taxa (redundancy), and one plant taxon might also produce many different phytolith types (multiplicity) (e.g., Fredlund \& Tieszen, 1994; Mulholland, 1989; Rovner, 1971). Also, the amount of morphological variation differs from taxon to taxon, as does the distinctiveness of morphotypes (Mulholland, 1989). Overall, there are many plant communities around the globe that provide diverse and recognizable phytolith assemblages (e.g., grasslands and savannahs in many tropical and temperate regions; cf. Strömberg, 2004 for a review), while other vegetation communities seem to leave less or no recognizable signatures (e.g., oak-pistachio forests; cf. Piperno, 2006 for a review).

Despite these methodological problems in the interpretation of phytolith data in paleoecological research, this is not an inevitable 

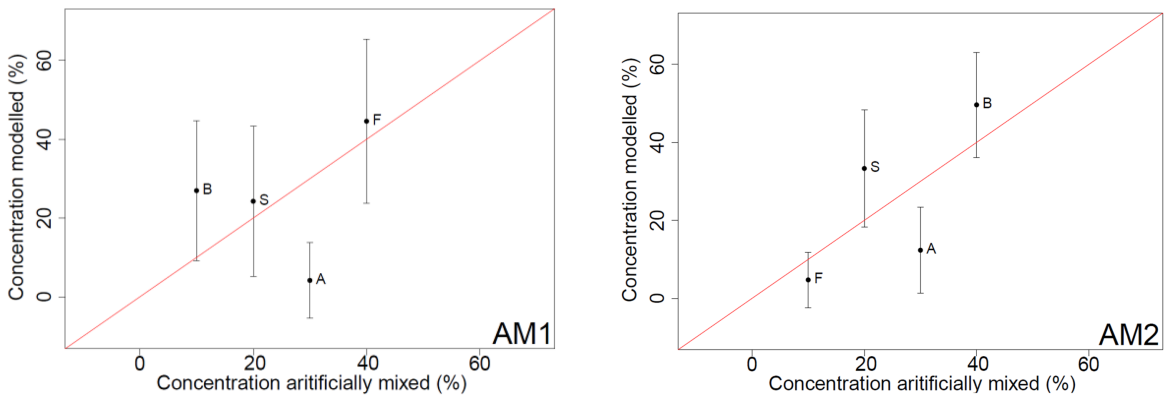

FIG URE 7 Artificial sediment mixture samples versus modelled results. The red line represents the optimum model. The letters A, B, F, S identify the sediment source contributions $(A=$ agricultural fields, $\mathrm{B}=$ badlands, $\mathrm{F}=$ forests, $\mathrm{S}=$ shrublands) [Color figure can be viewed at wileyonlinelibrary.com]
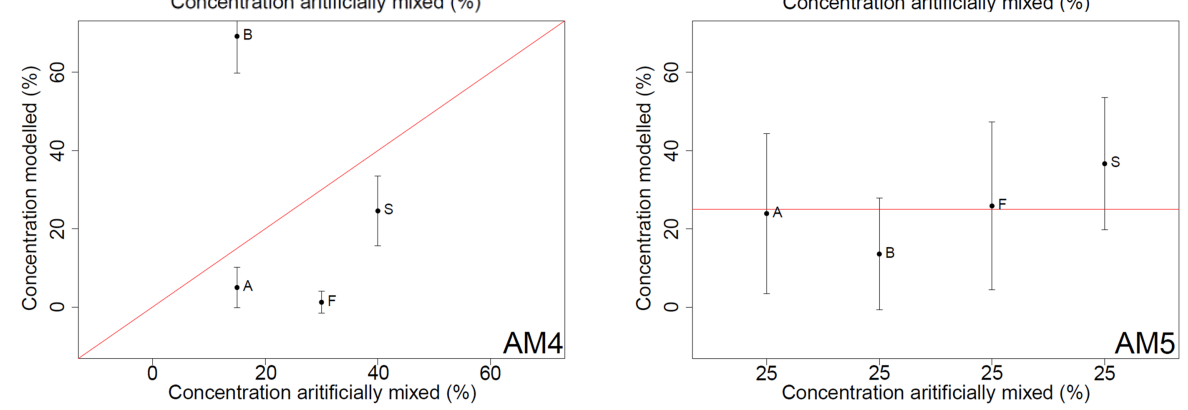

Natural Sediment Mixture Sample 2
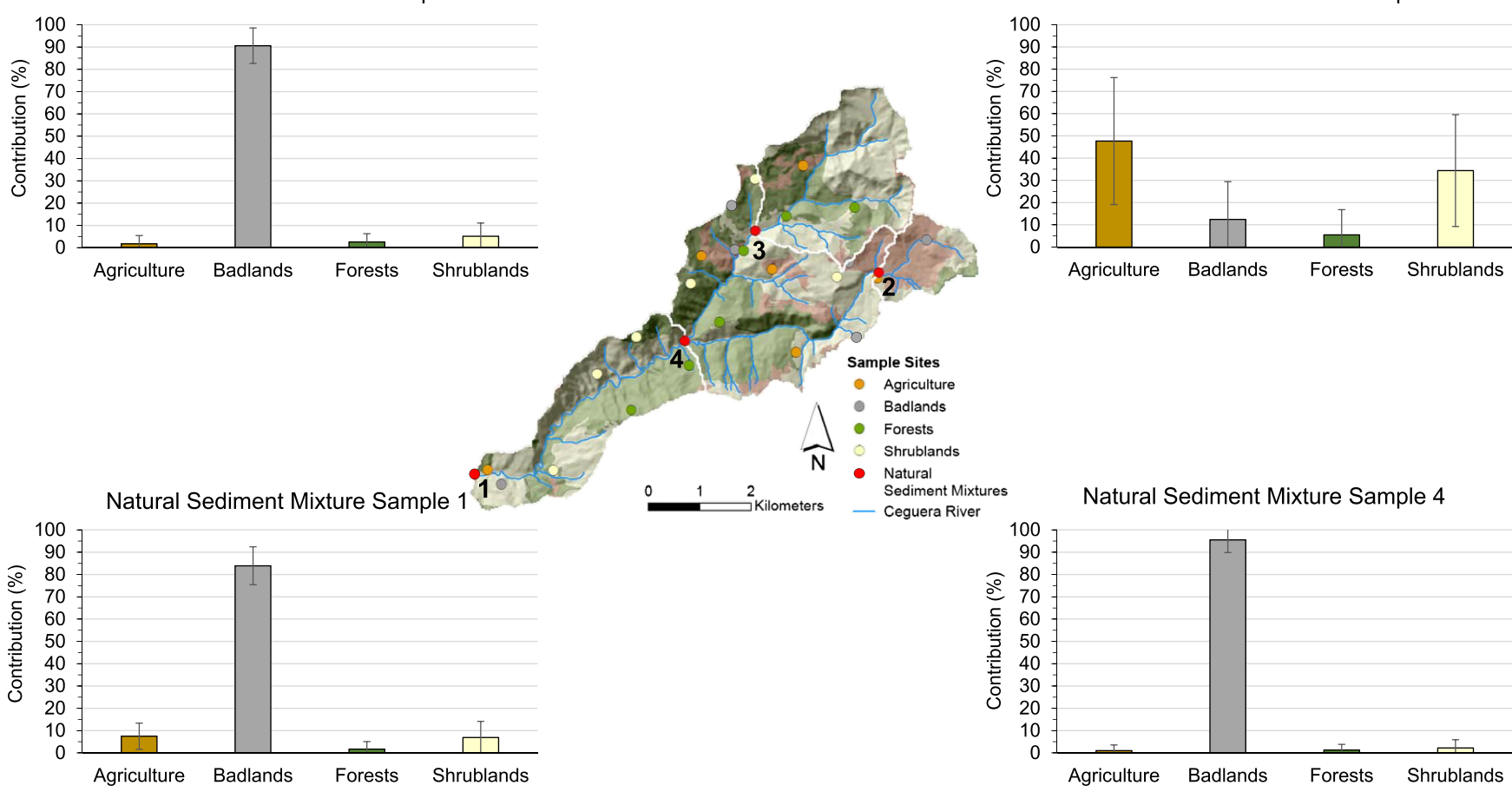

Natural Sediment Mixture Sample 4

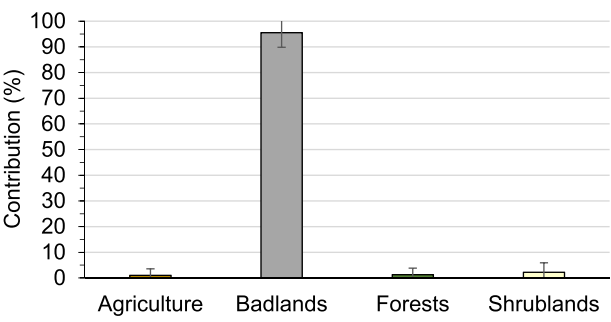

F I G U RE 8 Relative sediment source contribution (\%) to the four different natural sediment mixture samples in the Ceguera catchment [Color figure can be viewed at wileyonlinelibrary.com]

problem when considering phytoliths as tracers in sediment fingerprinting, as long as the phytolith assemblages and their morphotype concentrations within each investigated sediment source reflect the current land cover and are unique and, thus, allow discrimination between the sources (Figure 5). In this study, large agricultural areas of the Ceguera catchment were abandoned 60 years ago and are today shrublands or, if eroded, badlands (Arnaez et al., 2011; LópezVicente et al., 2011; Palazón et al., 2015). Apparently, enough time seems to have elapsed for the development of unique soil phytolith assemblages found in each land cover class.

Badlands, for instance, show as the main characteristic feature deeply incised gullies with exposed $\mathrm{C}$-horizons and a very sparse vegetation cover. Hence, total phytolith concentrations (Figure 2) and diversity of tracers (Figure 5) should be and are observably low. In contrast, forests and shrublands, as the least managed land cover classes, accumulate phytoliths in the topsoil layer (Figure 2) and show the highest phytolith concentrations. Forests also contain the most diverse set of phytolith tracers, displaying the highest succession gradients, whereas agricultural fields and shrublands fall into the intermediate range in line with their expected tracer diversity (Figure 5). In ploughed agricultural areas, phytoliths are assumed to be homogeneously incorporated into the first $30 \mathrm{~cm}$, reducing overall concentrations in the topsoil (Kraushaar et al., 2015). However, the average concentration for agricultural areas is only slightly lower than that of forests, even despite the yearly biomass extraction. This could be explained by the fact that certain vegetation types of agricultural 
lands (especially cereals) produce more phytoliths than other cultivated plant types (Piperno, 2006), or due to the increased two to three vegetation cycles per year.

Furthermore, the occurrence and observed concentrations of tracer morphotypes within the individual land cover classes can be well explained. Elongate dendritic long cells, for example, derived from inflorescence bracts of grasses (especially cereals; Ball et al., 1999), show the highest concentrations among agricultural areas. Tall rondel short cells, commonly produced in leaves, stems, and inflorescences of grasses, are found in all four land cover classes, while globular echinate morphotypes, which are commonly assigned to palms (Neumann et al., 2019), occur in forests and scrublands only, as expected. Additionally, the total concentration of phytoliths per gram of sediment (Figure 2), phytolith assemblages (Figure 3), and the selected phytolith tracers (Figure 5) show that natural sediment mixture samples display according to their contributing sources and, thus, very well reflect the relationship between those sources.

Discrimination between the sources is possible, as shown in Figure 6. However, badlands overlap completely with agriculture in the linear discriminant function scatter plot, similar to the findings of Brosinsky et al. (2014b). This causes these sources to be less distinctly identifiable and potentially over-rates the estimated badland contribution while under-rating the agricultural contribution.

\subsection{Constant in time}

When interpreting modern or past phytolith records in soils and sediments, it is necessary to discuss their origin. While large proportions of phytoliths are deposited by plant release directly into uppermost horizons of soils and sediments, representing a localized, in-situ deposition, phytoliths might also be transported and/or released by water runoff, wind, fire, or animal dung (Piperno, 2006), especially in arid environments with open landscapes (Fredlund \& Tieszen, 1994). Generally, there is also little information on how long it takes to develop soil phytolith assemblages from the plant phytolith assemblages from which they are derived. Thus, land cover changes can lead to a heritage of phytolith morphologies (i.e. the soil phytolith assemblage of a presently sparse vegetation site can potentially still show signs of a formerly existing vegetation cover). However, this does not pose an inevitable problem when considering phytoliths as tracer in sediment fingerprinting, as long as the phytolith assemblages of each sediment source are unique.

To investigate phytolith signatures of the contemporary vegetation, a systematic composite sampling of topsoils from underneath standing vegetation is the best option and was, therefore, applied in this study whenever possible. This reduces the effect of time conflation resulting from the incorporation of phytoliths into the A-horizon over a long period of time (Piperno, 2006), and it also diminishes the loss or input of phytoliths by various erosional and depositional processes and sources. The phytolith records examined here, therefore, reflect modern rather than old phytolith assemblages, or a mixture of both. When sampling natural sediment mixture samples in deposition areas, care must be taken that samples are only taken from locations without vegetation cover in order to prevent alterations in phytolith compositions and concentrations. Only fluvial sediments, such as bedload and/or suspended sediments, or freshly deposited sediments (e.g., during the last flood) without current vegetation cover or signs of pedogenetic processes, should be sampled in order to guarantee that the phytoliths tracer signal is constant in time.

\section{3 | Constant along a transport path}

Concentration changes due to physical corrosion, dissolution, and particle size selectivity are important to explore in any tracer, as they will affect the conservativism of the tracer along the transport path and perhaps prohibit the use of the tracer (Collins et al., 2017; Koiter et al., 2013).

Physical and chemical corrosion due to transport processes or differential preservation is an important issue, meaning that phytolith preservation varies and differential dissolution can occur, depending on the phytolith morphotypes and the chemical and physical characteristics of the depositional environment (Piperno, 2006). The phytolith assemblages of the studied topsoils, however, seem to be well preserved. Although multicellular phytolith forms were absent, as usual for soils and sediments due to a varied range of depositional and post-depositional processes (e.g., chemical and physical attack, bioturbation; Alexandre et al., 1997; Cabanes et al., 2011; Fraysse et al., 2009; Madella \& Lancelotti, 2012), the observed proportions of weathered phytolith morphotypes are remarkably low, averaging only to $0.6 \%$. The additional occurrence of less stable phytolith morphotypes, such as hair cells (Figure 4), which are rarely recovered from soils (Piperno, 2006), indicate that the topsoil assemblages of the Ceguera catchment are young and/or levels of phytolith dissolution on site are low. Hence, the impact of physical and chemical corrosion in meso-sized catchments, such as the Ceguera catchment, can be considered rather small due to short transport paths.

Furthermore, the transport of sediments from slopes into rivers and water reservoirs often causes a shift in the chemical milieus from aerobic to anaerobic conditions (Kraushaar et al., 2015). When choosing conservative tracers in sediment fingerprinting (e.g., chemical elements, physical parameters, or organic substances), it is important to ensure that they do not dissolve (e.g., potassium or iron; Kraushaar et al., 2015), chemically precipitate or get incorporated into the crystalline matrices (Collins et al., 2017), alter (e.g., colour), or even oxidize (e.g., pollen; Lebreton et al., 2010) during transport. The silica origin of the phytoliths makes them, in comparison, a relatively permanent component of sedimentary deposits (Cabanes et al., 2011), unlikely to be altered quickly by the chemical environment they move or deposit in. In terms of organic plant remains, they are the most durable terrestrial plant fossils known (Piperno, 2006).

Nevertheless, during transport, sediments (including the phytoliths) experience particle size selection processes due to different transport capacities and sedimentation scenarios. The particle size of a sediment sample exerts a strong influence on the concentration of many tracers used for fingerprinting (Koiter et al., 2013; Laceby et al., 2017). Fluvial deposits, for example, range from sandy to very clayey, depending on the local transport capacity of the river. Since phytoliths in the Ceguera catchment classify in the clay and silt fraction with less than $40 \mu \mathrm{m}$ in size, very sandy deposits could be diluted in their phytolith concentrations. In fingerprint studies, this problem is often considered by selecting narrow particle sizes (usually $\leq 63 \mu \mathrm{m}$ ) in all of the collected sediment samples, in order to allow comparability of tracer concentrations in source and mixture samples 
(Collins et al., 2017; Walling, 2005). In the case of the sample preparation method applied in this study, however, samples do not have to be sieved to a certain grain size prior to analysis. The counting process after the density separation focuses on the clay and silt fractions and then scales the result relative to the full sample weight.

\section{4 | Performance testing with artificial sediment mixture samples and observed erosion processes}

In this pilot study, with its limited sample size, three of four usable artificial sediment mixture sample concentrations were satisfactorily modelled, supporting the further investigation of phytoliths as a potentially suitable tracer (Figure 7). The lack of correctly estimated agricultural contributions, the high uncertainty associated with each modelled source contribution, as well as the low discrimination between badlands and agricultural samples calls for more samples per land cover class in future studies to reduce variance and better represent sources. Concerning the contribution results in the Ceguera catchments, all natural sediment mixture samples, except SM2, clearly show the badlands (followed by shrublands and agricultural areas) as the major contributing sediment sources (Figure 8). Natural sediment mixture sample 2 (Figure 8 ) indicates agricultural areas as the main contributor from an area that is mainly agriculturally used (Figure 1, natural sediment mixture sample 2). This finding coincides with field observations, showing strong signs of erosion, such as rill erosion and initial gullying, siltation in furrows, and sedimented roads in this particular area (Figure S9 $a-f$ ).

In some cases, the development of dendritic gully systems in the fields is already visible, rendering the affected areas inaccessible and preventing farming and, thus, displaying the genetic evolution from an agricultural area to a badland. However, when considering that badlands were not well discriminated from agricultural sources, it is unknown how much of the estimated badlands contributions derive from agricultural fields and vice versa. Nevertheless, badlands are known to have one of the highest erosion rates in the world, coupled with high lateral connectivity to the fluvial network (Bryan and Yair, 1982; Nadal-Romero et al., 2011). This is supported by the findings of García-Ruiz et al. (2013) who highlight, in their review on erosion in Mediterranean landscapes, badlands as the land use class with the highest erosion values of more than $1000 \mathrm{t} \mathrm{km}^{-2}$ per year. Similarly, fingerprinting studies from the Isábena region using different fingerprinting tracers identified the erosion contribution at a larger scale. Results have also pointed to badlands as the main contributor to the sediment yield. Brosinsky et al. (2014a) found a badland contribution of up to 85\%, and Palazón et al. $(2015,2016)$ and Palazón and Navas (2017) a badland subsoil contribution of $>80 \%$, with agriculture coming second (4-55\%) and shrublands and forests third $(<10 \%)$. Therefore, the main contributor coincides between the studies, whereas agriculture seems more erosive when assessed on a larger scale.

\section{6 | CONCLUSIONS AND OUTLOOK}

This pilot study aimed to assess phytoliths as quantitative process tracer in a sediment fingerprint study in the Spanish Pyrenees. Initial results show that the phytolith assemblages examined seem to be (i) unique to land cover classes, (ii) constant in time for the observed timescale of recent erosion, and (iii) physically and chemically conservative on site, during transport and deposition.

Validation of the sediment fingerprinting results using artificial sediment mixture samples provided satisfying results for the small sample size of this pilot study but need further testing with an extended sample. Erosion contributions modelled correspond to field observations, as well as to existing erosion and fingerprinting studies from the region that yield the same major contributors.

Based on current knowledge and similar to the suggestion of Bliedtner et al. (2018) for biomarkers, we assume that phytoliths can be applied well, especially in catchments which: (i) have a predominantly non-carbonatic origin, as an alkali environment potentially stimulates phytolith dissolution; (ii) are meso-sized $\left(<1000 \mathrm{~km}^{2}\right)$, thus preventing phytoliths from suffering extended corrosion due to long pathways; and (iii) show only minor changes in vegetation cover and/or land management practices within the last decades in order to expect unique phytolith assemblages in topsoil layers.

To gain additional knowledge on the potential and limitations of phytoliths in sediment fingerprinting, and to improve and develop the methodological approach, this pilot study identifies possible starting points for further research.

- Basic research: A regional reference collection of plants of the different land cover classes would facilitate the interpretation of phytolith production and deposition and provide a better understanding of the development of the unique tracer signal. Sediment and phytoliths dating of sediment source and mixture samples would provide an insight into the constancy of the tracer signal and what timescale of erosion is reflected in a catchment. A combination of soil and phytolith analyses would allow the assessment of pedogenetic processes and their influence on phytolith preservation and, thus, the conservatism of the tracer in situ and after deposition. Also, a comparison with other tracers would facilitate a detailed evaluation of the advantages and disadvantages of using phytoliths as tracers in sediment fingerprinting.

- Sampling: An intensification of sediment source samples could minimize variances in the land cover classes and better represent sources; more natural sediment mixture samples would allow better tracking of phytolith concentrations along the transport path. The use of additional artificial sediment mixture samples for validation would enable a better performance assessment of the tracer and method.

- Analysis: The comparison of phytolith concentrations between samples could be enhanced by scaling the lightest counted fraction not to its relative volume but the total of $1 \mathrm{~g}$ of sediment, this way imitating a selective grain size sampling. To reduce sample analysis time on the microscope, the development of an automated imagebased method for faster detection, counting, and classification of phytoliths by using machine learning techniques would be highly desirable. Also, the future implementation of a standardized method, such as Lizaga et al.'s (2020b) newly published consensus ranking for the rejection of nonconservative tracers, as well as the development of a standardized statistical protocol for the pre-selection of suitable (phytolith) tracers before the unmixing modelling, would be a necessary step to keep fingerprinting results comparable and guarantee quality standards. 
In future studies, to verify its applicability in sediment fingerprinting applications, it will also be important to test the phytoliths as tracers in other river basins and different environments.

\section{ACKNOWLEDGEMENTS}

The authors would like to thank Jakob Heinzle for his help in the field and Dr José A. López-Tarazón for the provision of GIS data and logistical advice. We are grateful to Philipp Garbe and Iris Müller from the University of Würzburg for their technical assistance during sample processing and phytolith extraction. Finally, we are grateful to the German and Austrian taxpayers, who financed the fieldwork through a student stipend from the Department of Earth Sciences of the Freie Universität Berlin and the 'Woman in Science' fund of the Faculty of Earth Sciences, Geography and Astronomy at the University of Vienna.

\section{CONFLICT OF INTEREST}

The authors report no conflict of interest.

\section{DATA AVAILABILITY STATEMENT}

The data which support the findings of this study are available in the online Supplementary Material for this article or from the corresponding author upon request.

\section{ORCID}

Sabine Kraushaar (i) https://orcid.org/0000-0001-8849-8162 Matthias Konzett (D) https://orcid.org/0000-0001-5843-9452 Janika Kiep (1D) https://orcid.org/0000-0002-5415-6321 Christian Siebert (D) https://orcid.org/0000-0001-7266-8112 Julia Meister (1D) https://orcid.org/0000-0003-1385-4112

\section{REFERENCES}

Albert, R.M. (2000) Study of ash layers through phytolith analyses from the Middle Paleolithic levels of Kebara and Tabun caves. Barcelona: Universitat de Barcelona Available at: http://hdl.handle.net/2445/ 42640

Albert, R.M., Lavi, O., Estroff, L., Weiner, S., Tsatskin, A., Ronen, A. \& LevYadun, S. (1999) Mode of occupation of Tabun Cave, Mt Carmel, Israel during the Mousterian Period: A study of the sediments and phytoliths. Journal of Archaeological Science, 26(10), 1249-1260. https://doi.org/10.1006/jasc.1999.0355

Albert, R.M. \& Weiner, S. (2001) Study of phytoliths in prehistoric ash layers using a quantitative approach. In: Meunier, J.D. \& Colin, F. (Eds.) Phytoliths, Applications in Earth Sciences and Human History. Lisse: Balkema, pp. 251-266.

Alexandre, A., Meunier, J.-D., Colin, F. \& Koud, J.-M. (1997) Plant impact on the biogeochemical cycle of silicon and related weathering processes. Geochimica et Cosmochimica Acta, 61(3), 677-682. https:// doi.org/10.1016/S0016-7037(97)00001-X

Arnaez, J., Lasanta, T., Errea, M.P. \& Ortigosa, L. (2011) Land abandonment, landscape evolution, and soil erosion in a Spanish Mediterranean mountain region: The case of Camero Viejo. Land Degradation \& Development, 22(6), 537-550. https://doi.org/10. 1002/ldr.1032

Ball, T.B., Gardner, J.S. \& Anderson, N. (1999) Identifying inflorescence phytoliths from selected species of wheat (Triticum monococcum, T. dicoccon, T. dicoccoides, and T. aestivum) and barley (Hordeum vulgare and $H$. spontaneum) (Gramineae). American Journal of Botany, 86(11), 1615-1623. https://doi.org/10.2307/2656798

Barboni, D., Bonnefille, R., Alexandre, A. \& Meunier, J.D. (1999) Phytoliths as paleoenvironmental indicators, West Side Middle Awash Valley,
Ethiopia. Palaeogeography, Palaeoclimatology, Palaeoecology, 152(1-2), 87-100. https://doi.org/10.1016/S0031-0182(99)00045-0

Bliedtner, M., Zech, R., Kühn, P., Schneider, B., Zielhofer, C. \& von Suchodoletz, H. (2018) The potential of leaf wax biomarkers from fluvial soil-sediment sequences for paleovegetation reconstructions - Upper Alazani River, central southern Greater Caucasus (Georgia). Quaternary Science Reviews, 196, 62-79. https://doi.org/10.1016/j. quascirev.2018.07.029

Boudreault, M., Koiter, A.J., Lobb, D.A., Liu, K., Benoy, G., Owens, P.N., et al. (2018) Using colour, shape and radionuclide fingerprints to identify sources of sediment in an agricultural watershed in Atlantic Canada. Canadian Water Resources Journal/Revue Canadienne Des Ressources Hydriques, 43(3), 347-365. https://doi.org/10.1080/ 07011784.2018.1451781

Bronstert, A., de Araújo, J.C., Batalla, R.J., Costa, A.C., Delgado, J.M., Francke, T., et al. (2014) Process-based modelling of erosion, sediment transport and reservoir siltation in mesoscale semi-arid catchments. Journal of Soils and Sediments, 14(12), 2001-2018. https:// doi.org/10.1007/s11368-014-0994-1

Brosinsky, A., Foerster, S., Segl, K. \& Kaufmann, H. (2014a) Spectral fingerprinting: Sediment source discrimination and contribution modelling of artificial mixtures based on VNIR-SWIR spectral properties. Journal of Soils and Sediments, 14(12), 1949-1964. https://doi.org/10. 1007/s11368-014-0925-1

Brosinsky, A., Foerster, S., Segl, K., López-Tarazón, J.A., Piqué, G. \& Bronstert, A. (2014b) Spectral fingerprinting: Characterizing suspended sediment sources by the use of VNIR-SWIR spectral information. Journal of Soils and Sediments, 14(12), 1965-1981. https://doi.org/10.1007/s11368-014-0927-z

Brown, D.A. (1984) Prospects and limits of a phytolith key for grasses in the central United States. Journal of Archaeological Science, 11(4), 345-368. https://doi.org/10.1016/0305-4403(84)90016-5

Brown, A.G. (1985) The potential use of pollen in the identification of suspended sediment sources. Earth Surface Processes and Landforms, 10, 27-32. https://doi.org/10.1002/esp.3290100106

Bryan, R.B. \& Yair, A. (1982) Badland Geomorphology and Piping. Norwich: Geo Books

Cabanes, D. \& Shahack-Gross, R. (2015) Understanding fossil phytolith preservation: The role of partial dissolution in paleoecology and archaeology. PLoS One, 10(5), e0125532. https://doi.org/10.1371/ journal.pone.0125532

Cabanes, D., Weiner, S. \& Shahack-Gross, R. (2011) Stability of phytoliths in the archaeological record: A dissolution study of modern and fossil phytoliths. Journal of Archaeological Science, 38(9), 2480-2490. https://doi.org/10.1016/j.jas.2011.05.020

Collins, A.L., Pulley, S., Foster, I.D.L., Gellis, A., Porto, P. \& Horowitz, A.J. (2017) Sediment source fingerprinting as an aid to catchment management: A review of the current state of knowledge and a methodological decision-tree for end-users. Journal of Environmental Management, 194, 86-108. https://doi.org/10.1016/j.jenvman.2016. 09.075

Collins, A.L. \& Walling, D.E. (2002) Selecting fingerprint properties for discriminating potential suspended sediment sources in river basins. Journal of Hydrology, 261(1-4), 218-244. https://doi.org/10.1016/ S0022-1694(02)00011-2

Corine Land Cover. 2018. Available at: https://land.copernicus.eu/paneuropean/corine-land-cover/clc2018

Dietrich, L., Meister, J., Dietrich, O., Notroff, J., Kiep, J., Heeb, J., et al. (2019) Cereal processing at Early Neolithic Göbekli Tepe, southeastern Turkey. PLoS One, 14(5), e0215214. https://doi.org/10.1371/ journal.pone.0215214

Fargas, D., Casasnovas, J.M. \& Poch, R. (1997) Identification of critical sediment source areas at regional level. Physics and Chemistry of the Earth, 22(3-4), 355-359. https://doi.org/10.1016/S0079-1946(97) 00158-4

Francke, T., Werb, S., Sommerer, E. \& López-Tarazón, J.A. (2014) Analysis of runoff, sediment dynamics and sediment yield of subcatchments in the highly erodible Isábena catchment, Central Pyrenees. Journal of Soils and Sediments, 14(12), 1909-1920. https://doi.org/10.1007/ s11368-014-0990-5 
Fraysse, F., Pokrovsky, O.S., Schott, J. \& Meunier, J.-D. (2009) Surface chemistry and reactivity of plant phytoliths in aqueous solutions. Chemical Geology, 258(3-4), 197-206. https://doi.org/10.1016/j. chemgeo.2008.10.003

Fredlund, G.G. \& Tieszen, L.T. (1994) Modern phytolith assemblages from the North American Great Plains. Journal of Biogeography, 21(3), 321-335. https://doi.org/10.2307/2845533

García-Ruiz, J.M., Nadal-Romero, E., Lana-Renault, N. \& Beguería, S. (2013) Erosion in Mediterranean landscapes: Changes and future challenges. Geomorphology, 198, 20-36. https://doi.org/10.1016/j. geomorph.2013.05.023

Gaspar, L., Blake, W.H., Smith, H.G., Lizaga, I. \& Navas, A. (2019) Testing the sensitivity of a multivariate mixing model using geochemical fingerprints with artificial mixtures. Geoderma, 337, 498-510. https:// doi.org/10.1016/j.geoderma.2018.10.005

Haddadchi, A., Ryder, D.S., Evrard, O. \& Olley, J. (2013) Sediment fingerprinting in fluvial systems: Review of tracers, sediment sources and mixing models. International Journal of Sediment Research, 28(4), 560-578. https://doi.org/10.1016/S1001-6279(14)60013-5

Koiter, A.J., Owens, P.N., Petticrew, E.L. \& Lobb, D.A. (2013) The behavioural characteristics of sediment properties and their implications for sediment fingerprinting as an approach for identifying sediment sources in river basins. Earth-Science Reviews, 125, 24-42. https:// doi.org/10.1016/j.earscirev.2013.05.009

Kraushaar, S., Schumann, T., Ollesch, G., Schubert, M., Vogel, H.-J. \& Siebert, C. (2015) Sediment fingerprinting in northern Jordan: Element-specific correction factors in a carbonatic setting. Journal of Soils and Sediments, 15(10), 2155-2173. https://doi.org/10.1007/ s11368-015-1179-2

Laceby, J.P., Evrard, O., Smith, H.G., Blake, W.H., Olley, J.M., Minella, J.P. G. \& Owens, P.N. (2017) The challenges and opportunities of addressing particle size effects in sediment source fingerprinting: $A$ review. Earth-Science Reviews, 169, 85-103. https://doi.org/10. 1016/j.earscirev.2017.04.009

Lebreton, V., Messager, E., Marquer, L. \& Renault-Miskovsky, J. (2010) A neotaphonomic experiment in pollen oxidation and its implications for archaeopalynology. Review of Palaeobotany and Palynology, 162 (1), 29-38. https://doi.org/10.1016/j.revpalbo.2010.05.002

Liu, L., Li, D., Jie, D., Liu, H., Gao, G. \& Li, N. (2019) Translocation of phytoliths within natural soil profiles in Northeast China. Frontiers in Plant Science, 10, 1-15. https://doi.org/10.3389/fpls.2019.01254

Lizaga, I., Latorre, B., Gaspar, L. \& Navas, A. (2018) FingerPro: An R package for sediment source tracing. Available at: https://doi.org/10. 5281/zenodo.1402029

Lizaga, I., Latorre, B., Gaspar, L. \& Navas, A. (2020a) FingerPro: An R package for tracking the provenance of sediment. Water Resources Management, 34(12), 3879-3894. https://doi.org/10.1007/s11269020-02650-0

Lizaga, I., Latorre, B., Gaspar, L. \& Navas, A. (2020b) Consensus ranking as a method to identify non-conservative and dissenting tracers in fingerprinting studies. Science of the Total Environment, 720, 137537. https://doi.org/10.1016/j.scitotenv.2020.137537

López-Tarazón, J.A., Batalla, R.J. \& Vericat, D. (2011) In-channel sediment storage in a highly erodible catchment: The River Isábena (Ebro Basin, Southern Pyrenees). Zeitschrift für Geomorphologie, NF, 55(3), 365-382. https://doi.org/10.1127/0372-8854/2011/0045

López-Tarazón, J.A., Batalla, R.J., Vericat, D. \& Balasch, J.C. (2010) Rainfall, runoff and sediment transport relations in a mesoscale mountainous catchment: The River Isábena (Ebro basin). Catena, 82(1), 23-34. https://doi.org/10.1016/j.catena.2010.04.005

López-Tarazón, J.A., Batalla, R.J., Vericat, D. \& Francke, T. (2009) Suspended sediment transport in a highly erodible catchment: The River Isábena (Southern Pyrenees). Geomorphology, 109(3-4), 210-221. https://doi.org/10.1016/j.geomorph.2009.03.003

López-Tarazón, J.A., Batalla, R.J., Vericat, D. \& Francke, T. (2012) The sediment budget of a highly dynamic mesoscale catchment: The River Isábena. Geomorphology, 138(1), 15-28. https://doi.org/10.1016/j. geomorph.2011.08.020

López-Vicente, M., Lana-Renault, N., García-Ruiz, J.M. \& Navas, A. (2011) Assessing the potential effect of different land cover management practices on sediment yield from an abandoned farmland catchment in the Spanish Pyrenees. Journal of Soils and Sediments, 11(8), 1440-1455. https://doi.org/10.1007/s11368-011-0428-2

Loucaides, S., Cappellen, P.V. \& Behrends, T. (2008) Dissolution of biogenic silica from land to ocean: Role of salinity and pH. Limnology and Oceanography, 53(4), 1614-1621. https://doi.org/10.4319/lo.2008. 53.4.1614

Madella, M., Alexandre, A. \& Ball, T. (2005) International code for phytolith nomenclature 1.0. Annals of Botany, 96(2), 253-260. https://doi.org/ 10.1093/aob/mci172

Madella, M. \& Lancelotti, C. (2012) Taphonomy and phytoliths: A user manual. Quaternary International, 275, 76-83. https://doi.org/10. 1016/j.quaint.2011.09.008

Manjoro, M., Rowntree, K., Kakembo, V., Foster, I. \& Collins, A.L. (2017) Use of sediment source fingerprinting to assess the role of subsurface erosion in the supply of fine sediment in a degraded catchment in the Eastern Cape, South Africa. Journal of Environmental Management, 194, 27-41. https://doi.org/10.1016/j.jenvman.2016. 07.019

Mulholland, S.C. (1989) Phytolith shape frequencies in North Dakota grasses: A comparison to general patterns. Journal of Archaeological Science, 16(5), 489-511. https://doi.org/10.1016/0305-4403(89) 90070-8

Mulholland, S.C. \& Rapp, G., Jr. (1992a) A morphological classification of grass silica-bodies. In: Mulholland, S.C. \& Rapp, G., Jr. (Eds.) Phytolith Systematics - Emerging Issues, Advances in Archaeological and Museum Science. New York: Springer Science \& Business Media, pp. 65-89.

Mulholland, S.C. \& Rapp, G., Jr. (1992b) Phytolith Systematics - Emerging Issues. New York: Springer Science \& Business Media.

Nadal-Romero, E., Martínez-Murillo, J.F., Vanmaercke, M. \& Poesen, J. (2011) Scale-dependency of sediment yield from badland areas in Mediterranean environments. Progress in Physical Geography: Earth and Environment, 35(3), 297-332. https://doi.org/10.1177/ 0309133311400330

Neumann, K., Fahmy, A., Lespez, L., Ballouche, A. \& Huysecom, E. (2009) The Early Holocene palaeoenvironment of Ounjougou (Mali): Phytoliths in a multiproxy context. Palaeogeography, Palaeoclimatology, Palaeoecology, 276(1-4), 87-106. https://doi.org/10.1016/j.palaeo. 2009.03.001

Neumann, K., Strömberg, C.A.E., Ball, T., Albert, R.M., Vrydaghs, L. \& Cummings, L.S. (2019) International code for phytolith nomenclature (ICPN) 2.0. Annals of Botany, 124(2), 189-199. https://doi.org/10. 1093/aob/mcz064

Owens, P.N., Blake, W.H., Gaspar, L., Gateuille, D., Koiter, A.J., Lobb, D.A., et al. (2016) Fingerprinting and tracing the sources of soils and sediments: Earth and ocean science, geoarchaeological, forensic, and human health applications. Earth-Science Reviews, 162, 1-23. https:// doi.org/10.1016/j.earscirev.2016.08.012

Palazón, L., Gaspar, L., Latorre, B., Blake, W.H. \& Navas, A. (2015) Identifying sediment sources by applying a fingerprinting mixing model in a Pyrenean drainage catchment. Journal of Soils and Sediments, 15(10), 2067-2085. https://doi.org/10.1007/s11368-015-1175-6

Palazón, L., Latorre, B., Gaspar, L., Blake, W.H., Smith, H.G. \& Navas, A. (2016) Combining catchment modelling and sediment fingerprinting to assess sediment dynamics in a Spanish Pyrenean river system. Science of the Total Environment, 569, 1136-1148.

Palazón, L. \& Navas, A. (2016) Land use sediment production response under different climatic conditions in an alpine-prealpine catchment Catena, 137, 244-255. https://doi.org/10.1016/j.catena.2015. 09.025

Palazón, L. \& Navas, A. (2017) Variability in source sediment contributions by applying different statistic test for a Pyrenean catchment. Journal of Environmental Management, 194, 42-53. https://doi.org/10.1016/ j.jenvman.2016.07.058

Pearsall, D.M. (2000) Paleoethnobotany: A Handbook of Procedures. Amsterdam: Elsevier.

Pearsall, D.M., Chandler-Ezell, K. \& Chandler-Ezell, A. (2004) Maize can still be identified using phytoliths: Response to Rovner. Journal of Archaeological Science, 31(7), 1029-1038. https://doi.org/10.1016/j.jas. 2003.11.007 
Pearsall, D.M. \& Trimble, M.K. (1984) Identifying past agricultural activity through soil phytolith analysis: A case study from the Hawaiian islands. Journal of Archaeological Science, 11(2), 119-133. https://doi. org/10.1016/0305-4403(84)90047-5

Piperno, D.R. (1988) Phytolith Analysis: An Archaeological and Geological Perspective. New York: Academic Press.

Piperno, D.R. (2006) Phytoliths: A Comprehensive Guide for Archaeologists and Paleoecologists. Lanham, MD: Altamira.

Portillo, M., Kadowaki, S., Nishiaki, Y. \& Albert, R.M. (2014) Early Neolithic household behavior at Tell Seker al-Aheimar (Upper Khabur, Syria): A comparison to ethnoarchaeological study of phytoliths and dung spherulites. Journal of Archaeological Science, 42, 107-118. https:// doi.org/10.1016/j.jas.2013.10.038

Rovner, I. (1971) Potential of opal phytoliths for use in paleoecological reconstruction. Quaternary Research, 1(3), 343-359. https://doi.org/ 10.1016/0033-5894(71)90070-6

Smith, H.G. \& Blake, W.H. (2014) Sediment fingerprinting in agricultural catchments: A critical re-examination of source discrimination and data corrections. Geomorphology, 204, 177-191. https://doi.org/10. 1016/j.geomorph.2013.08.003

Strömberg, C.A.E. (2004) Using phytolith assemblages to reconstruct the origin and spread of grass-dominated habitats in the great plains of North America during the late Eocene to early Miocene. Palaeogeography, Palaeoclimatology, Palaeoecology, 207(3-4), 239-275. https://doi.org/10.1016/j.palaeo.2003.09.028

Tsartsidou, G., Lev-Yadun, S., Albert, R.-M., Miller-Rosen, A., Efstratiou, N. \& Weiner, S. (2007) The phytolith archaeological record: Strengths and weaknesses evaluated based on a quantitative modern reference collection from Greece. Journal of Archaeological
Science, 34(8), 1262-1275. https://doi.org/10.1016/j.jas.2006. 10.017

Twiss, P.C., Suess, E. \& Smith, R.M. (1969) Morphological classification of grass phytoliths. Soil Science Society of America Journal, 33(1), 109-115. https://doi.org/10.2136/sssaj1969.03615995003300010030x

Valero-Garcés, B.L., Navas, A., Machín, J. \& Walling, D. (1999) Sediment sources and siltation in mountain reservoirs: A case study from the Central Spanish Pyrenees. Geomorphology, 28(1-2), 23-41. https:// doi.org/10.1016/S0169-555X(98)00096-8

Walling, D.E. (2005) Tracing suspended sediment sources in catchments and river systems. Science of the Total Environment, 344(1-3), 159-184. https://doi.org/10.1016/j.scitotenv.2005.02.011

Weisskopf, A., Qin, L., Ding, J., Ding, P., Sun, G. \& Fuller, D.Q. (2015) Phytoliths and rice: From wet to dry and back again in the Neolithic Lower Yangtze. Antiquity, 89, 1051-1063. https://doi.org/10. 15184/aqy.2015.94

\section{SUPPORTING INFORMATION}

Additional supporting information may be found online in the Supporting Information section at the end of this article.

How to cite this article: Kraushaar S, Konzett M, Kiep J, Siebert C, Meister J. Suitability of phytoliths as a quantitative process tracer for soil erosion studies. Earth Surf. Process. Landforms. 2021;46:1797-1808. https://doi.org/10.1002/esp. 5121 